\title{
Effect of the neuropeptide phoenixin and its receptor GPR173 during folliculogenesis
}

\author{
Xuan Phuoc Nguyen", Tomoko Nakamura', Satoko Osuka ${ }^{1,2}$, Bayasula Bayasula ${ }^{3}$, \\ Natsuki Nakanishi ${ }^{1}$, Yukiyo Kasahara ${ }^{1}$, Ayako Muraoka ${ }^{1}$, Shotaro Hayashi ${ }^{1}$, Takashi Nagai $^{1}$, \\ Tomohiko Murase ${ }^{1}$, Maki Goto ${ }^{1}$, Akira Iwase ${ }^{4}$ and Fumitaka Kikkawa ${ }^{1}$ \\ ${ }^{1}$ Department of Obstetrics and Gynecology, Nagoya University Graduate School of Medicine, Nagoya, Japan, \\ ${ }^{2}$ Department of Maternal and Perinatal Medicine, Nagoya University Hospital, Nagoya, Japan, ${ }^{3}$ Bell Research \\ Center for Reproductive Health and Cancer; Department of Obstetrics and Gynecology, Nagoya University \\ Graduate School of Medicine, Nagoya, Japan and ${ }^{4}$ Department of Obstetrics and Gynecology, Gunma University \\ Graduate School of Medicine, Maebashi, Gunma, Japan \\ Correspondence should be addressed to T Nakamura; Email: tomonakamura@med.nagoya-u.ac.jp
}

\begin{abstract}
Folliculogenesis is a complex process, defined by the growth and development of follicles from the primordial population. Granulosa cells (GCs) play a vital role in every stage of follicular growth through proliferation, acquisition of gonadotropic responsiveness, steroidogenesis and production of autocrine/paracrine factors. A recently discovered hypothalamic neuropeptide phoenixin is involved in the regulation of the reproductive system. Phoenixin acts through its receptor, G protein-coupled receptor 173 (GPR173), to activate the CAMP/PKA pathway leading to the phosphorylation of CREB (pCREB). Here, we demonstrated the expression patterns of phoenixin and GPR173 in human ovary and explored its role in folliculogenesis. Phoenixin and GPR173 were both expressed in the human ovarian follicle, with increased expression in GCs as the follicle grows. Phoenixin treatment at $100 \mathrm{nM}$ for $24 \mathrm{~h}$ induced the proliferation of human non-luteinized granulosa cell line, $\mathrm{HGrC1}$ and significantly increased the expression levels of CYP19A1, FSHR, LHR and KITL, but decreased NPPC expression levels. These effects were suppressed by GPR173 siRNA. The expression level of CREB1, pCREB and estradiol (E2) production in the culture medium was significantly enhanced by phoenixin treatment in a concentration-dependent manner. Phoenixin also significantly increased the follicular area in a murine ovarian tissue culture model, leading to an increased number of ovulated oocytes with a higher level of maturation. Taken together, our data demonstrate that phoenixin is an intraovarian factor that promotes follicular growth through its receptor GPR173 by accelerating proliferation of GCs, inducing E2 production and increasing the expression of genes related to follicle development.

Reproduction (2019) 158 25-34
\end{abstract}

\section{Introduction}

Ovarian folliculogenesis starts with the recruitment of primordial follicles to join the pool of growing primary, secondary and pre-antral follicles, which is regulated by intrinsic germinal and somatic factors. These follicles continue to develop with the formation of antrum, and only a subset of antral follicles, known as dominant follicles can reach the pre-ovulatory stage to subsequently successfully ovulate (Hirshfield 1991). It is widely established that the hypothalamic-pituitarygonadal (HPG) axis plays a primary role in controlling the terminal stages of folliculogenesis. Gonadotropinreleasing hormone $(\mathrm{GnRH})$ is secreted by the hypothalamus to stimulate the production of pituitary gonadotropins namely follicle-stimulating hormone $(\mathrm{FSH})$ and luteinizing hormone $(\mathrm{LH})$. Exposure of the ovary to $\mathrm{FSH}$ and $\mathrm{LH}$ results in the growth of follicles.
Accordingly, GCs of developing follicles become sensitive to gonadotropins and secrete increasing amounts of estradiol (E2) (Drummond \& Findlay 1999) which feeds back to the pituitary affecting the release of gonadotropins (Hirshfield 1991). Paracrine interactions between the oocyte and surrounding GCs, via a range of locally secreted growth factors and cytokines, are also critical for normal ovarian function and follicular development (Hirshfield 1991, Hsueh et al. 2015). Lately, much attention has been given to several neuropeptides, which in addition to their classical role in the nervous system, are thought to act as intraovarian factors to regulate follicle development (McGuire \& Bentley 2010).

Phoenixin, a highly conserved peptide among species, was recently discovered using a bioinformatics algorithm which utilized information provided by the Human Genome Project (Yosten et al. 2013). 
The precursor protein for phoenixin is the small integral membrane protein 20 (SMIM20), which contains a potential cleavage site at the C-terminal glycine. The two predominant peptides generated from SMIM20 are phoenixin-14 and phoenixin-20, each 14 and 20 amino acids in length, respectively. The original study described that the hypothalamus had the most abundant expression in terms of phoenixin immunoreactivity, and its specific binding was highest in the hypothalamus, with less amounts in the ovary and anterior pituitary (Yosten et al. 2013). Two independent groups have identified that phoenixin acts through the orphan receptor GPR173 and activates the cAMP, protein kinase A (PKA) pathway to induce cAMP response element-binding protein (CREB) phosphorylation (Stein et al. 2016, Treen et al. 2016). GPR173 is a member of a small subfamily of GPCRs called the Super Conserved Receptor Expressed in Brain (SREB) family which includes two other orphan receptors GPR27 and GPR85. The high degree of conservation of the protein-coding mRNA region across species indicates that they might play an important evolutionary role. In humans, GPR173 is widely distributed in the hypothalamus, pituitary and ovaries which share the identical HPG axis (Matsumoto et al. 2000).

Phoenixin was initially described as a reproductive peptide associated with the HPG axis since it regulates LH release from female pituitary cultures by inducing $\mathrm{GnRH}$ receptor mRNA (GnRHR) (Yosten et al. 2013). Studies have determined that intracerebroventricular injection of phoenixin increased $\mathrm{GnRH}$ (Jiang et al. 2015) and LH plasma levels (Stein et al. 2016). In support of these findings, in vitro phoenixin treatment in a GnRH-producing cell model increased the expression of GnRH and GnRHR mRNA as well as $\mathrm{GnRH}$ secretion. Additionally, siRNA knockdown of phoenixin led to a delay of estrus in female rats (Yosten et al. 2013). Within the hypothalamus, phoenixin and GPR173 are found to be expressed in multiple regions related to reproductive control including the arcuate nucleus (ARC) and anteroventral periventricular nucleus (AVPV). Despite extensive characterization of phoenixin in other peripheral tissues (Prinz et al. 2017, Schalla \& Stengel 2018, Stein et al. 2018), the potential existence of phoenixin and GPR173 in human gonads, and particularly their possible role in human GC regulation has not been discovered yet.

In the present study, we examined the expression of phoenixin in human ovarian follicles and studied its function in GCs. We also analyzed the effects of phoenixin in folliculogenesis using murine ovarian tissue cultures.

\section{Materials and methods \\ Ovarian tissues and immunohistochemistry}

Samples of surgically removed ovarian tissues were obtained from eight women in reproductive age (19-32 years old). Patients were selected based on a history of regular menstrual cycles and without any use of an intrauterine device or hormone therapy for more than 6 months prior to surgery. The selected eight women were patients undergoing surgical procedures for cervical cancer. This study was approved by the Ethical Committee of the Nagoya University Graduate School of Medicine. All patients provided written informed consent prior to recruitment. The ovarian tissue samples were fixed in $10 \%$ neutral buffered formalin and embedded in paraffin. Immunohistochemical staining was performed using the avidin-biotin immunoperoxidase method and Histofine SAB-PO kit (Nichirei Biosciences Inc., Tokyo, Japan), according to the manufacturers protocol. Briefly, endogenous peroxidase activity was blocked by $3 \%$ hydrogen peroxide in methanol for $15 \mathrm{~min}$. Nonspecific IgG binding was blocked using $10 \%$ normal rabbit serum in phosphate buffered saline (PBS). Tissue sections were incubated at $4{ }^{\circ} \mathrm{C}$ overnight with anti-phoenixin-14 antibody (H-079-01, 1:500 dilution, Phoenix Pharmaceuticals Inc., CA, USA) and antiGPR173 antibody (ab188765, 6.4 $\mathrm{gg} / \mathrm{mL}$, Abcam). Rabbit immunoglobulin G (IgG) was used as a negative control. Slides were then counterstained with Meyer's hematoxylin (Wako Pure Chemical Industries, Ltd, Osaka, Japan) at room temperature for $2 \mathrm{~min}$. The immunoreactivity intensity of phoenixin and GPR173 were graded as follows: (-) faint or very weak, $(+)$ weak, $(++)$ moderate and $(+++)$ strong. The images of prepared slides were observed using AXIO Imager A1 (Carl Zeiss Microscopy Co., Ltd.).

\section{HGrC1 cell culture and knockdown using siRNA}

HGrC1 cells were seeded into six-well collagen-coated dishes (Biocoat, Becton Dickinson and Co.) and cultured at $37^{\circ} \mathrm{C}$ in Dulbecco's modified Eagle's medium (DMEM, Sigma) supplemented with $10 \%$ fetal bovine serum (FBS, Sigma), $100 \mathrm{IU} / \mathrm{mL}$ of penicillin, $100 \mu \mathrm{g} / \mathrm{mL}$ of streptomycin and $25 \mathrm{mg} / \mathrm{L}$ of amphotericin B. Cells were treated with or without phoenixin-20 (No.079-03, Phoenix Pharmaceuticals Inc.) at $10 \mathrm{nM}$ or $100 \mathrm{nM}$ concentrations.

In case of siRNA experiment, HGrC1 cells were transfected with $10 \mathrm{nM}$ of GPR173 siRNA (Hs_GPR173_9962, SigmaAldrich Co. LLC., MO, USA) and $10 \mathrm{nM}$ of Stealth RNAi siRNA Negative Control was used as a negative control (no. 12935114, Life Technologies/Invitrogen) for $24 \mathrm{~h}$ using LipofectamineRNAiMax (Life Technologies/Invitrogen), following the manufacturer's instructions, and then cells were treated with phoenixin $100 \mathrm{nM}$. After $24 \mathrm{~h}$ of incubation, the culture medium and whole-cell extracts were obtained for biochemical analyses.

\section{MTS assay}

HGrC1 cells were seeded into a 96-well plate at a density of 5000 cells per well and incubated for $24 \mathrm{~h}$ in DMEM supplemented with $10 \%$ FBS. After starving for $12 \mathrm{~h}$, the cells were treated with $10 \mathrm{nM}, 100 \mathrm{nM}$ and $1000 \mathrm{nM}$ of phoenixin. Cell viability was measured after 12 and $24 \mathrm{~h}$ using 3-(4,5-dimethylthiazol-2-yl)-5-(3-carboxymethoxyphenyl)-2(4-sulfophenyl)-2H-tetrazolium inner salt (MTS), according to the manufacturer's instructions (Promega Corporation). 
Absorbance was measured at a wavelength of $490 \mathrm{~nm}$ with a Viento $808 \mathrm{IU}$ absorbance reader (BioTek, Japan).

\section{Reverse transcription-polymerase chain reaction}

mRNA was extracted from cells cultured in $35 \mathrm{~mm}$ dishes, using RNeasy Mini Kit (Qiagen Inc.) following the manufacturer's protocol. A reverse transcription (RT) reaction with $1 \mu \mathrm{g}$ of total RNA was carried out using a first-strand cDNA synthesis kit (ReverTraAce- $\alpha-$; Toyobo Co., Ltd., Osaka, Japan). Later, $1 \mu \mathrm{L}$ of the RT reaction product was used to PCR amplify SMIM20 and GPR173. The primers used are shown in Table 1. We used glyceraldehyde-3-phosphate dehydrogenase (GAPDH) as an internal control. Amplification was performed using Taq polymerase (PerkinElmer) for 35 cycles. The PCR protocol was denaturation at $94^{\circ} \mathrm{C}$ for $1 \mathrm{~min}$, annealing at $54^{\circ} \mathrm{C}$ for $1 \mathrm{~min}$ and extension at $72^{\circ} \mathrm{C}$ for $1 \mathrm{~min}$. The PCR products were separated on a $1.5 \%$ agarose gel in Tris-acetate-EDTA buffer, and the amplified bands were visualized by ethidium bromide staining. The cDNA obtained from treated cells was diluted 1:10, and real-time PCR (qPCR) was performed in a 96-well, $0.2 \mathrm{~mL}$ thin-wall PCR plates using the Thermal Cycler Dice (TaKaRa Bio Inc.). The real-time PCR mixture contained KOD SYBR qPCR Mix (Toyobo Co., Ltd.) $(10 \mu \mathrm{L})$, primers $(2 \mu \mathrm{M})$ and cDNA template $(1 \mu \mathrm{g})$ in a total volume of $20 \mu \mathrm{L}$. The primers used were GAPDH, Cytochrome P450 Family 19 Subfamily A Member 1 (CYP19A1), cAMP response elementbinding protein 1 (CREB1), FSHR, LHR, KITL and natriuretic peptide precursor C (NPPC) and are shown in Table 1. The PCR protocol was as follows: initial incubation at $98^{\circ} \mathrm{C}$ for $2 \mathrm{~min}$, denaturation at $98^{\circ} \mathrm{C}$ for $10 \mathrm{~s}$ and annealing at $60^{\circ} \mathrm{C}$ for $10 \mathrm{~s}$ ( 45 cycles) and extension at $68^{\circ} \mathrm{C}$ for $30 \mathrm{~s}$. qPCR was performed in triplicates for all samples. Quantification was performed by calculating the ratio of gene of interest to GAPDH mRNA using the comparative $\mathrm{Ct}$ method.

\section{Western blot analysis}

To detect pCREB, HGrC1 cells were cultured in DMEM without FBS for $12 \mathrm{~h}$. The cells were then treated with $10 \mathrm{nM}$ and $100 \mathrm{nM}$ of phoenixin-20 for 5, 15, 30 and $60 \mathrm{~min}$. After treatment, $\mathrm{HGrC1}$ cells were lysed and the isolated proteins were resolved by SDS-PAGE and transferred onto PVDF membranes and western blotting was performed as described previously (Nakamura et al. 2015). Membranes were immunoblotted with anti-CREB (1:500) and anti-pCREB (Ser133) (1:500) antibodies (Cell Signaling Technology).

\section{Murine ovarian tissue culture and follicle dynamic analysis}

Ovaries were isolated from 4-week-old female ICR mice (Charles River Laboratories Japan, Inc., Yokohama, Japan). All mice were housed in an environmentally controlled room at $23 \pm 1^{\circ} \mathrm{C}$ with a $12 \mathrm{~h}$ light: $12 \mathrm{~h}$ darkness cycle photoperiod. Animal experiments were approved by The Animal Experimental Committee of Nagoya University Graduate School of Medicine. The ovarian tissue slices were placed in a $30 \mathrm{~mm}$ cell culture insert (Merck Millipore Ltd.) and cultured as described in previous papers from our group (Komatsu et al. 2015, Murase et al. 2018). The culture medium was Minimum Essential Medium Alpha GlutaMax (Thermo Fisher Scientific Inc.) supplemented with $5 \%(\mathrm{v} / \mathrm{v})$ fetal bovine serum (Biological Industries Ltd., Beit HaEmek, Israel), $100 \mathrm{mIU} / \mathrm{mL}$ of $\mathrm{FSH}$ and $10 \mathrm{mIU} / \mathrm{mL}$ of $\mathrm{LH}$ (Merck KGaA). Phoenixin $10 \mathrm{nM}$ or $100 \mathrm{nM}$ was added to the culture medium. Cultured ovarian slices were imaged at $24 \mathrm{~h}$ intervals using a confocal microscope (FV1000, Olympus). ImageJ software (National Institutes of Health) was used to measure the area of each follicle. A tablet pen (Intuos, Wacom Co., Ltd., Kazo, Japan) was used to draw the outlines of the follicles in the captured bright-field images and the number of pixels in each follicle was measured and converted into the area $\left(\mu \mathrm{m}^{2}\right)$. The area of each follicle was tracked as follicular growth. Follicles with an intact basal lamina and a dark oocyte or absence of de-lineation of the oocyte membrane were classified as atretic follicles (Murase et al. 2018). Extruded oocytes were isolated and the meiotic phase of oocytes was determined. Oocytes at the germinal vesicle (GV) stage were classified by the presence of a clear GV, if the clear GV was not visible, oocytes were classified as metaphase I (MI), and metaphase II (MII) oocytes were classified by the disappearance of the clear GV and the appearance of a characteristic first polar body. Fragmented or shrunken oocytes were classified as degenerated (D). Ovarian tissue slices at the end of the culturing process were embedded in paraffin. The embedded ovarian tissue was sliced into $6 \mu \mathrm{m}$ sections and stained with hematoxylin and eosin. Follicles were classified and counted under $400 \times$ magnification with an

Table 1 List of primers for human granulosa cells ( $\mathrm{HGrC} 1)$ experiments $\left(5^{\prime}-3^{\prime}\right)$.

\begin{tabular}{lll}
\hline & Forward primer sequence & Reverse primer sequence \\
\hline GAPDH & CAGCCTCAAGATCATCAGCA & GTCTTCTGGGTGGCAGTGAT \\
SMIM20 & GCCGCCTTCTATCCCATCTAC & GCCCGATTTATAGCTTGTTCCT \\
GPR173 & CTGCACAAGGCTCCTTACTAC & CAGCCATAAAGGCCACAATCTTA \\
CYP19A1 & GGTGAGAGAGACATAAAGATTG & TTCAGGATAATGTTTGTCCC \\
FSHR & GCGGAACCCCAACATCGTGTC & TGAAGAAATCTCTGGGAAAGT \\
LHR & GATGTTACGAAGGTCTTCTC & AAAAGCATTTCCTGGTATGG \\
KITL & TCAGTCTTAAGTAGGGTGAATTGG & AAACGCTCACTTTGGTGCAT \\
NPPC & AGCCTGGGCTCGCCTT & CTTGTTGGCTCCTTTGTATTTGC \\
CREB1 & ACTGTAACGGTGCCAACTCC & GAATGGTAGTACCCGGCTGA \\
\hline
\end{tabular}

CREB1, CAMP response element-binding protein 1; CYP19A1, cytochrome P450 family 19 subfamily A member 1; FSHR, follicle-stimulating hormone receptor; GAPDH, glyceraldehyde-3-phosphate dehydrogenase; GPR173, G protein-coupled receptor 173; KITL, kit ligand; LHR, luteinizing hormone receptor; NPPC, Natriuretic peptide precursor C; SMIM20, small integral membrane protein 20. 
AXIO Imager A1 (Carl Zeiss Microscopy Co., Ltd.) as reported previously (Roy et al. 2012). We defined primordial follicles as those containing flat GCs, primary follicles as those with a single layer of cuboidal GCs, secondary follicles as those having two to five layers of cuboidal GCs and antral follicles as those surrounded by more than five layers of GCs forming the antral cavity.

\section{E2 radioimmunoassay}

To detect the presence of E2, HGrC cells were cultured in phenol red-free DMEM (Sigma) supplemented with 10\% fetal bovine serum (FBS, Sigma), $100 \mathrm{IU} / \mathrm{mL}$ of penicillin, $100 \mu \mathrm{g} / \mathrm{mL}$ of streptomycin and $25 \mathrm{mg} / \mathrm{L}$ of amphotericin B. Before the $\mathrm{HGrC1}$ cells were treated with phoenixin-20 for $24 \mathrm{~h}, 10 \mu \mathrm{M}$ androstenedione (4-androstene-3,17-dione; Sigma) was added to the culture medium. The medium from murine ovarian tissue culture was collected after $48 \mathrm{~h}$ of phoenixin incubation, on day 2 , before treatment with $100 \mathrm{mIU} / \mathrm{mL}$ of $\mathrm{LH}$. After treatment, the culture medium from control and treated groups was collected and centrifuged at $150 \times \mathbf{g}$ for $15 \mathrm{~min}$. The supernatants were transferred to fresh tubes and stored at $-80^{\circ} \mathrm{C}$ until the samples were sent for E2 measurement (SRL Inc., Aichi, Japan).

\section{Statistical analysis}

All experimental data are presented as the mean \pm S.E.M. Student's $t$-test was applied to compare the means between the two groups. One-way ANOVA with Bonferroni's pairwise multiple comparison test was used to determine the statistical differences between multiple groups. All statistical analyses were performed using the SigmaPlot 13 software (Systat Software Inc., San Jose, CA, USA). A $P$ value $<0.05$ was considered as statistically significant.

\section{Results}

\section{Expression of phoenixin and GPR173 in human ovarian follicles}

The expression levels and cellular distribution patterns of phoenixin and GPR173 in the human ovarian tissue were evaluated by immunohistochemistry. Although phoenixin and GPR173 immunoreactivity was negative in GCs of primordial follicles, they were positive in follicles of each developmental stage after the primary follicles stage. The GCs of the primary follicles showed weak staining of both phoenixin and GPR173 (Fig. 1A and $\mathrm{B}, \mathrm{b})$. GC immunostaining was detectable in multilayered secondary follicles (Fig. 1A and B, c) and was most intense in antral follicle and corpus luteum (Fig. 1A and B, d, e). Both phoenixin and GPR173 immunostaining were prominently detected in oocytes in human ovary (Fig. 1A and B, a, b, c). Theca cells of the secondary and antral follicle showed weak staining with phoenixin and GPR173 (Fig. 1A and B, C, d).

PCR results revealed that the mRNAs of SMIM20 (77bp) and GPR173 (154bp) were expressed in the HGrC1 cell line (Fig. 1D). Thus, phoenixin and its receptor GPR173 were expressed in human follicular GCs and $\mathrm{HGrC} 1$ cells with increasing expression as the follicular stage develops (Fig. 1C).

\section{Effect of phoenixin on GC proliferation}

To determine whether phoenixin might affect GC proliferation, the extent of cell proliferation was measured by MTS assay. HGrC1 cells incubated with $10 \mathrm{nM}, 100 \mathrm{nM}$ and $1000 \mathrm{nM}$ of phoenixin indicated significantly increased proliferation after $24 \mathrm{~h}$ of treatment, with maximal effect being observed at $100 \mathrm{nM}(P<0.01)$ (Fig. 2). These results demonstrated that phoenixin-induced proliferation in a time- and concentration-dependent manner.

\section{Effect of phoenixin on GPR173 expression, CREB activation and GC steroidogenesis}

We next investigated whether phoenixin regulates steroidogenesis, which is one of the primary functions of GCs. Phoenixin induced the expression of steroidogenesis-related genes in a concentrationdependent manner. Treatment with $100 \mathrm{nM}$ phoenixin caused a significant increase in the expression of GPR173 (2.13-fold, $P<0.01)$, CREB1 (1.44-fold, $P<0.05)$ and CYP19A1 (4.03-fold, $P<0.01$ ) in HGrC1 cells (Fig. 3A, $\mathrm{B}$ and $\mathrm{C}$ ). In addition, phoenixin at $10 \mathrm{nM}$ and $100 \mathrm{nM}$ concentrations increased the phosphorylation of CREB after 15 and $30 \mathrm{~min}$ of treatment (Fig. 3D). Phoenixininduced E2 production in a concentration-dependent manner, especially with a significant induction at $100 \mathrm{nM}(34.10 \pm 1.60$ vs $24.90 \pm 2.40 \mathrm{pg} / \mathrm{mL}$ respectively, $P<0.05)$ compared with the control group (Fig. $3 \mathrm{E}$ ).

\section{Effect of phoenixin on the expression of follicle development-related genes}

We further measured the effect of phoenixin on the expression of FSHR, LHR, KITL and NPPC, which are related to folliculogenesis. Phoenixin at a concentration of $100 \mathrm{nM}$ significantly increased the mRNA levels of FSHR (5.78-fold, $P<0.001)$, LHR (4.89-fold, $P<0.001$ ) and KITL (2.54-fold, $P<0.05)$, but decreased the mRNA levels of NPPC $(0.54$-fold, $P<0.01)$ in HGrC1 cells (Fig. 4A, B, C and D). Phoenixin at $10 \mathrm{nM}$ concentration showed a significant induction only in FSHR mRNA levels (1.71-fold) (Fig. 4A).

\section{GPR173 mediated the effect of phoenixin in GCs}

To confirm whether GPR173 mediates the effect of phoenixin in GCs, specific GPR173 siRNA was used to knockdown endogenous GPR173 before treatment with phoenixin. The qPCR results showed that treatment with 10 nM GPR173 siRNA significantly suppressed GPR173 mRNA $(48 \%, P<0.05)$ expression in human GCs 
A

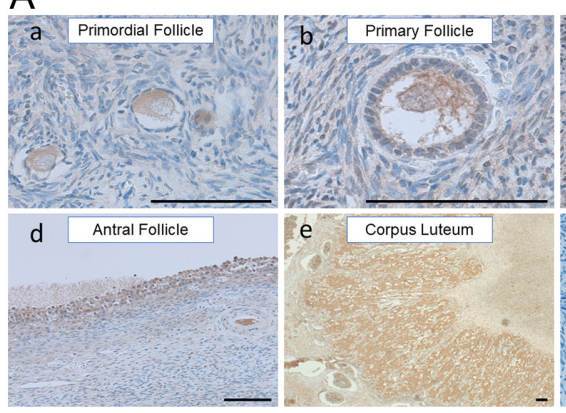

C

\begin{tabular}{lllllll}
\hline Follicle & & Primordial & Primary & Secondary & Antral & $\begin{array}{l}\text { Corpus } \\
\text { Luteum }\end{array}$ \\
& & & & & & \\
\hline Granulosa cells & PNX & $\mathrm{Neg}$ & ++ & ++ & +++ & +++ \\
& GPR173 & $\mathrm{Neg}$ & + & ++ & +++ & +++ \\
\hline
\end{tabular}

B
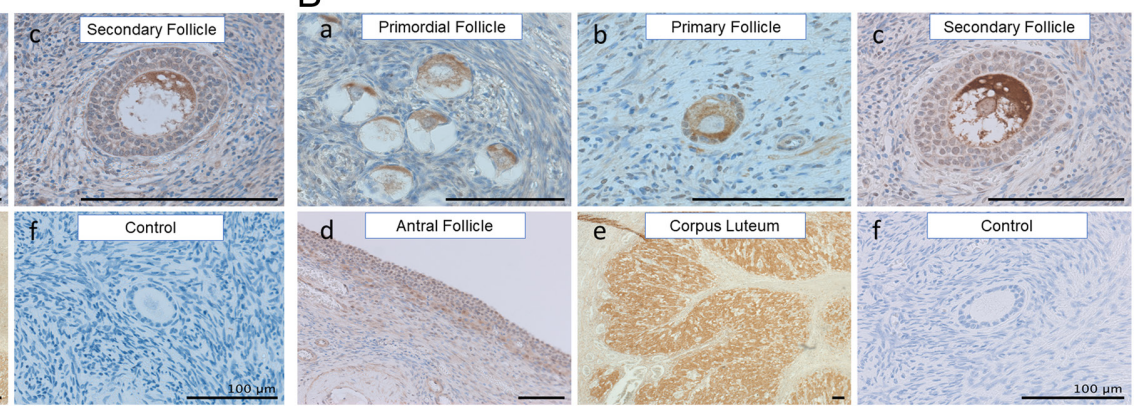

D

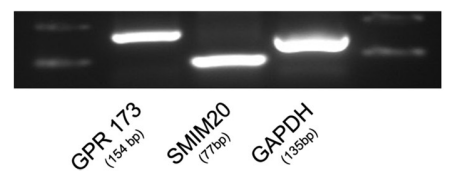

Figure 1 (A, B, C and D) Expression of phoenixin and GPR173 in human ovarian follicles. Localization of phoenixin (A) and GPR173 (B) in primordial (a), primary (b), secondary (c), antral (d), corpus luteum and (e) ovarian follicles by immunohistochemistry. DAB-immunoperoxidase staining was performed on paraffin-embedded human ovarian tissue using antibodies against phoenixin or GRP173, or rabbit lgG (negative control (f)). (C) Summary of the expression of phoenixin and GPR173 in granulosa cells of each follicular stage. (D) Total mRNA expression in the human non-luteinized granulosa cell line (HGrC1). RT-PCR was performed to amplify SMIM20 (77 bp) and GPR173 (154bp) fragments. The scale bars represent $100 \mu \mathrm{m}$.

(Fig. 5A). GPR173 silencing significantly impaired the induction of CYP19A1, FSHR, LHR, KITL (Fig. 5B, D, E and $\mathrm{F}$ ) and reduction of $\mathrm{C}$-type natriuretic peptide (CNP) mRNA expression (Fig. 5G) by phoenixin. Unfortunately, we could not observe any significant difference in E2 production in GCs pre-incubated with GPR173 siRNA (Fig. 5C).

\section{Effect of phoenixin on follicular growth}

The immunoreactivity of phoenixin and its receptor GPR173 was confirmed in murine ovarian tissues (Supplementary Fig. 1, see section on supplementary data given at the end of this article). The pattern of phoenixin expression was extremely similar between human and mouse ovarian tissues.

To evaluate follicular development when treated with phoenixin, mouse ovarian tissue culture method and time-lapse analysis (Fig. 6A), developed by our group (Komatsu et al. 2015, Murase et al. 2018) were used. In the first week of ovarian tissue culture, the average area of follicles between the three treatment groups did not show a significant difference. However, in the ovarian tissues induced with $100 \mathrm{nM}$ of phoenixin, significant differences were observed from day 9 to the last day of culture. At $10 \mathrm{nM}$, phoenixin-induced follicle growth, however, with slower and less effect (Fig. 6B). After treatment with $100 \mathrm{nM}$ of phoenixin for 2 days, the mean E2 production in the culture medium was significantly higher $\quad(298.00 \pm 62.48$ vs $\quad 177.67 \pm 23.68 \mathrm{pg} / \mathrm{mL}$ respectively, $P<0.05)$ in comparison to control (Fig. 6C). Throughout the culture period, the number of ovulated oocytes were counted and evaluated for their developmental stages. The addition of $10 \mathrm{nM}$ or $100 \mathrm{nM}$ of phoenixin to the culture medium markedly increased the average number of ovulated oocytes $(19.00 \pm 1.15,17.67 \pm 1.45$ vs. $12.67 \pm 1.76, P<0.05)$ (Fig. 6D). Additionally, phoenixin treatment resulted in a higher proportion of matured oocytes at MI and MII stages (Fig. 6E) with a statistically significant difference in tissues treated with $100 \mathrm{nM}$ phoenixin (54.72 vs $26.32 \%, P<0.01)$. The percentage of GV oocytes were lower in phoenixin-treated tissue which showed a significant decrease in the $100 \mathrm{nM}$ group compared with the control group. (18.87 vs $44.74 \%, P<0.01$ ).

The number of follicles in each stage from tissues harvested at the end of culture period were counted (Fig. 6F). After 16 days, ovarian tissue slices cultured with

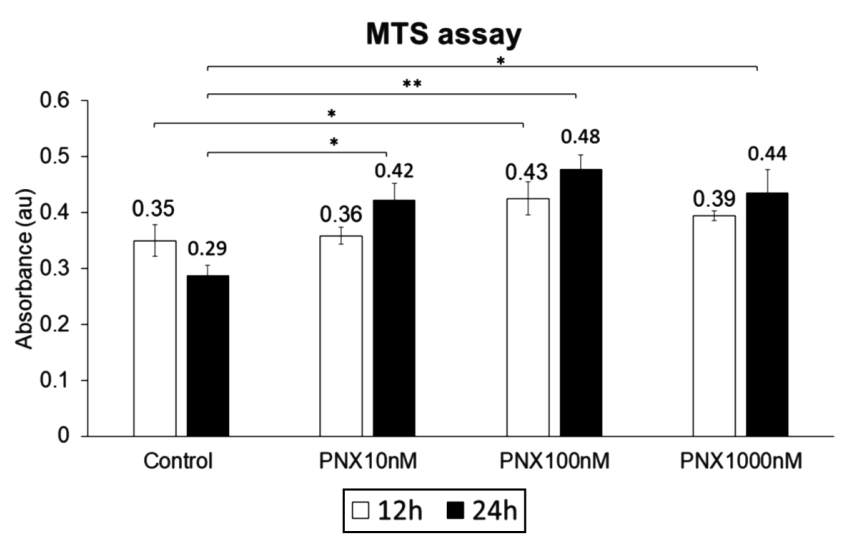

Figure 2 Effect of phoenixin on GC proliferation. HGrC1 cells were treated with phoenixin for $12 \mathrm{~h}$ and $24 \mathrm{~h}$ and cell proliferation was detected by MTS assay. Mean \pm S.D. ${ }^{*} P<0.05,{ }^{* *} P<0.01$. 

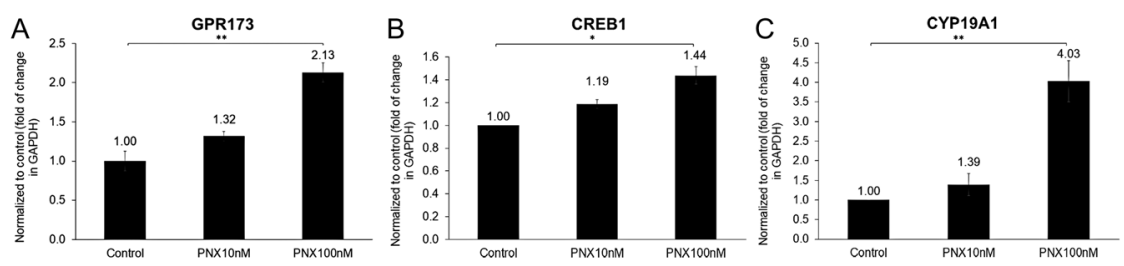

D

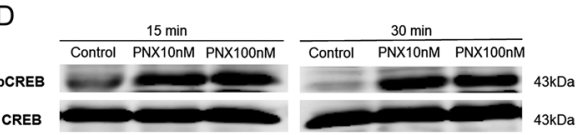

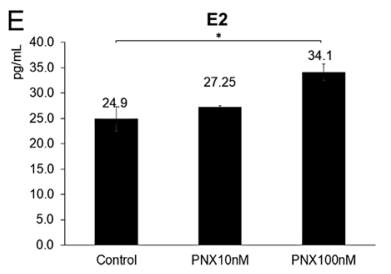

Figure 3 Effect of phoenixin on GPR173 expression, CREB activation and GC steroidogenesis. (A), (B) and (C) GPR173, CREB1, CYP19A1 mRNA expression was measured by quantitative PCR in $\mathrm{HGrC1}$ cells after treatment with $10 \mathrm{nM}$ and $100 \mathrm{nM}$ of phoenixin. (D) Western blotting measured the protein levels of CREB and PCREB after treatment with $10 \mathrm{nM}$ and $100 \mathrm{nM}$ of phoenixin for 15 and $30 \mathrm{~min}$. (E) The concentration of E2 in the culture medium was detected by chemiluminescent immunoassay system. Mean \pm S.D. ${ }^{*} P<0.05,{ }^{* *} P<0.01$.
$10 \mathrm{nM}$ or $100 \mathrm{nM}$ of phoenixin showed a significantly higher proportion of secondary follicles $(6.77 \%$ and $8.76 \%$ vs $2.60 \%$, respectively, $P<0.01)$ and antral follicles $(1.93 \%$ and $2.21 \%$ vs $0.07 \%$, respectively, $P<0.05)$ and a lower proportion of primordial follicles $(41.10 \%$ and $36.39 \%$ vs $47.93 \%$, respectively, $P<0.01)$ compared with those in the control group. The proportion of primary follicles tended to increase with phoenixin treatment; however, there was no significant difference between the three groups. These results indicated that phoenixin enhances follicular growth, ovulated oocyte numbers and maturity of ovulated oocytes in mouse ovarian tissue culture.

\section{Discussion}

Phoenixin was originally discovered as a neuropeptide regulating the reproductive system (Yosten et al. 2013). The relatively high levels of expression in the hypothalamus led previous reports to speculate that its main role was in the hypothalamus. The full-length cDNA of phoenixin has also been detected in the ovary of chicken by conventional PCR method (Bédécarrats et al. 2016). GPR173 has previously been discovered in the ovary of rats (Stein et al. 2016, Bauman et al. 2017), bovine (Hatzirodos et al. 2014) and humans (Matsumoto et al. 2000). Our study is the first to show the correlation between the expression of phoenixin and GPR173 in each stage of follicular growth in human and murine ovarian follicles. Phoenixin and GPR173 were expressed in oocytes, GCs and theca cells of the human ovarian follicle. Notably, phoenixin and GPR173 in GCs were detected in primary follicles, increased along with the stages of follicle development and showed the strongest expression in the secondary to antral follicle stages. The human GCs also expressed the mRNA of phoenixin precursor protein SMIM20 and its receptor, GPR173. Altogether, these data show that human GCs are both able to produce and respond to phoenixin, suggesting a paracrine or autocrine effect of phoenixin in human ovarian follicles. Especially, the strongest expression in the secondary to antral follicle stages implied that phoenixin might play an important role in these stages of follicle development.

Growth and development of ovarian follicles is accompanied by a marked process of GC proliferation and differentiation (Kranc et al. 2017). Phoenixin significantly increased $\mathrm{HGrC1}$ proliferation in a concentration- and time-dependent manner, whereas the control group showed decrease due to serum starvation. In the heart, phoenixin has been shown to decrease myocardial apoptosis by enhancing the expression of the anti-apoptotic factor, $\mathrm{Bcl}-2$ and reducing proapoptotic factors such as Bax, Caspase 3, Cytochrome $\mathrm{C}$ and p38 MAPK (Rocca et al. 2018). Phoenixin might have induced proliferation in part by reducing apoptosis in GCs via the same mechanism. Steroidogenesis is another critical role of GCs. Estradiol, which is mainly produced by the GCs, is converted from androgen by CYP19A1 (Drummond 2006, Stocco 2008). Phoenixin has been shown to act on GPR173 to activate the CAMP/PKA pathway leading to the activation of CREB thereby inducing increased GnRH mRNA expression in
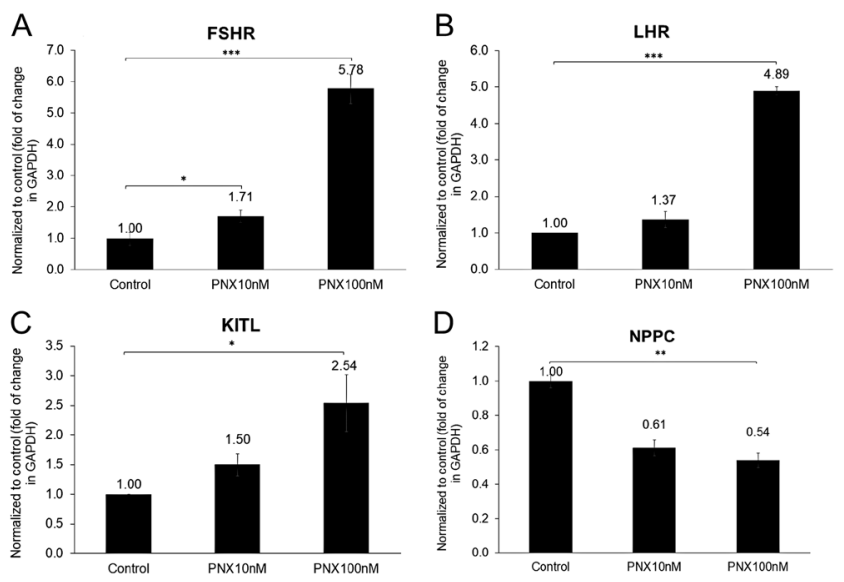

Figure 4 Effect of phoenixin on the expression of follicle development-related genes in GCs. (A), (B), (C) and (D) FSHR, LHR, KITL and NPPC mRNA expression levels were measured by qPCR in HGrC1 cells after treatment with $10 \mathrm{nM}$ and $100 \mathrm{nM}$ of phoenixin. Mean \pm S.D. ${ }^{*} P<0.05,{ }^{* *} P<0.01,{ }^{* * *} P<0.001$. 


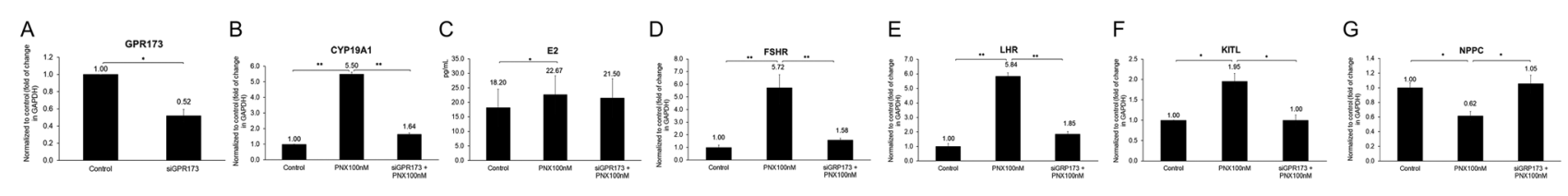

Figure 5 GPR173 mediated the effect of phoenixin in GCs. (A) GPR173 mRNA expression was measured by qPCR in HGrC1 cells after transfecting with $10 \mathrm{nM}$ of GPR173 targeting siRNA for $24 \mathrm{~h}$. (B, D, E, F and G) CYP19A1, FSHR, LHR, KITL and NPPC mRNA expression levels were measured by quantitative PCR in $\mathrm{HGrC1}$ cells after treatment with $100 \mathrm{nM}$ phoenixin post $24 \mathrm{~h}$ of transfection with or without GPR173 siRNA. (C) The concentration of E2 in the culture medium was detected by chemiluminescent immunoassay system. Mean \pm S.D. $* P<0.05, * * P<0.01$.

GnRH neurons (Matsumoto et al. 2000, Treen et al. 2016). In the peripheral tissues, phosphorylated CREB has been reported to activate the conserved CAMP response element (CRE) sequences present in the promoter of the CYP19A1 gene and regulate the expression of aromatase activity in GCs (Conkright et al. 2003, Carlezon et al. 2005, Stocco 2008, Zhang et al. 2018). In HGrC1 cells, which have been shown to maintain non-luteinized GC characteristics and steroidogenesis (Bayasula et al. 2012), phoenixin increased phosphorylated CREB, upregulated the expression of CYP19A1 mRNA and increased E2 production. Although siGPR173 reversed the phoenixininduced effects on the expression of genes that we have studied, the effect on E2 production was subtle (Fig. 5C). To synthesize E2 from androstenedione, 17ß-HSD is also necessary as well as CYP19A1. Androstenedione is converted to testosterone by $17 \mathrm{~B}-\mathrm{HSD}-1$ and testosterone to $\mathrm{E} 2$ by CYP19A1. Androstenedione is also converted to estrone by CYP19A1, and estrone to E2 by 17ß-HSD-1. Although we have not studied the effects of phoenixin on 17ß-HSD-1 activity and/or production in this study, the subtle effect of siGPR173 and phoenixin on E2 production vs CYP19A1 mRNA expression could be attributed to 17 ß-HSD-1.

The growth of a follicle in each stage is distinct and controlled by diverse endocrine and paracrine factors, which control the communication among GCs as well as between GCs and oocytes (Sánchez \& Smitz 2012, Hsueh et al. 2015). The expression of FHSR and LHR in GCs is essential for GC proliferation, differentiation, apoptosis and hormone synthesis (Menon et al. 2005, Kishi et al. 2018). Aberrant expression of these receptors can lead to arrested follicular development (Menon \& Menon 2012). KITL promotes primordial to primary follicle transition and increases the diameter of oocytes from growing primary follicles (Carlsson et al. 2006, Thomas \& Vanderhyden 2006, Hutt et al. 2006a,b). CNP, encoded by the NPPC gene, is known to inhibit oocyte maturation (Kawamura et al. 2011). Our experiments demonstrated that phoenixin increased FSHR, LHR, KITL mRNA, while it decreased NPPC mRNA in GCs. These results suggest that phoenixin might contribute to GCs acquiring gonadotropin sensitivity, thus promoting follicle growth. Phoenixin-induced increase in KITL
A
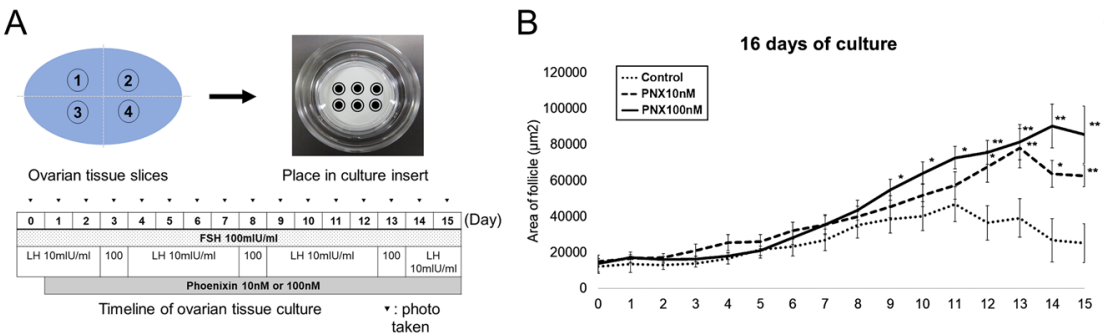

D

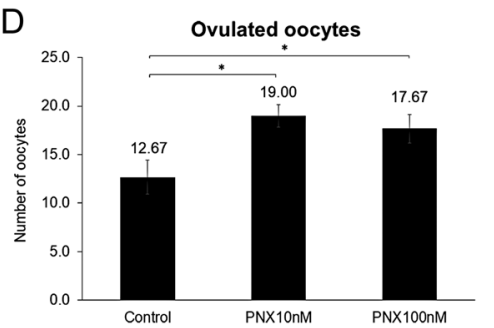

B

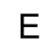

$\mathrm{E}$

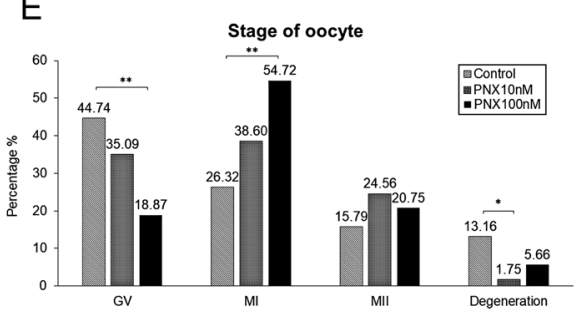

C

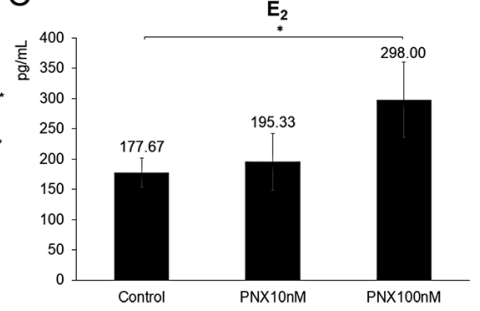

$\mathrm{F}$

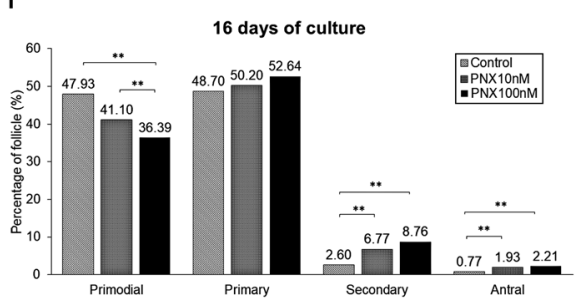

Figure 6 Effect of phoenixin on murine follicular growth. (A) Illustration of ovarian tissue culture method. (B) Phoenixin (10 nM and $100 \mathrm{nM}$ ) was added into the culture medium. The graphs represent change in the area of follicles observed after 16 days of culture. (C) The concentration of estradiol in the ovarian tissue culture medium was detected by chemiluminescent immunoassay system. (D) The number of ovulated oocytes during culture period. (E) The percentage of released oocytes of each meiotic phase (GV, MI, MII or degeneration) observed during culture period. (F) The proportion of the types of follicles in ovarian tissue, collected the end of the culture process. Mean \pm S.D. ${ }^{*} P<0.05,{ }^{* *} P<0.01$. 
and decrease in NPPC expression might resume oocyte meiosis and induce oocyte maturity. These findings suggest that phoenixin could act as an intraovarian factor to regulate follicle development-related gene expression.

Phoenixin and GPR173 immunoreactivities were also identified in mouse ovary with similar expression pattern as observed in human ovary. In accordance with our molecular findings, phoenixin promoted follicle growth and oocyte maturity in our ex vivo studies with murine ovarian tissue culture. The average follicular area, the proportion of secondary and antral follicles and E2 production were increased with phoenixin treatment in a concentration-dependent manner. In our study, follicle enlargement was seen in the later stages of follicular growth, which coincides with increased expression of the phoenixin receptor GPR173. The percentage of primordial follicles decreased with a corresponding increase in the percentage of secondary and antral follicles, supporting the potential role of phoenixin in follicles with multiple layers of GCs. Subsequently, phoenixin treatment increased the number and improved the maturity of ovulated oocytes. Previous reports have indicated that larger follicular size corresponds with improved quality of oocytes (Xiao et al. 2015, Murase et al. 2018). Phoenixin might improve the maturity of ovulated oocytes by assisting follicular growth. We cannot exclude the possibility of a direct effect of phoenixin/GPR173 on oocytes since both phoenixin and GPR173 were strongly expressed in oocytes.

Polycystic ovary syndrome (PCOS) is characterized by steroidogenesis dysregulation, follicle growth interruption and chronic anovulation (Escobar-Morreale 2018). Interestingly, plasma phoenixin levels were elevated in women with PCOS (Ullah et al. 2017) and revealed a potential involvement of phoenixin in the pathogenesis of PCOS. It will be our future interest to examine the expression and functionality of phoenixin and GPR173 in GCs from PCOS patients with an attempt to gain a better understanding of the role of phoenixin in the development of PCOS.

A prior investigation has shown that phoenixin was co-expressed with nesfatin-1 in several hypothalamic nuclei. Besides, phoenixin and GPR173 have been found to be expressed in the hypothalamic ARC and AVPV which classically express kisspeptin (Yosten et al. 2013, Osuka et al. 2016, Stein et al. 2016). Both nesfatin-1 and kisspeptin have been identified in the gonad and regulate the function of steroidogenesis (García-Galiano \& Tena-Sempere 2013, Garcia-Ortega et al. 2014, Kim et al. 2014, Hu et al. 2017, Owens et al. 2018). Further, phoenixin upregulated Kiss1 mRNA expression in kisspeptin neurons (Treen et al. 2016). Altogether, these previous studies not only strongly suggest the interplay between phoenixin, nesfatin-1 and kisspeptin in the ovary but also broaden the scope of understanding for many other neuropeptide systems as well, which are produced both in central and peripheral reproductive tissues
(McGuire \& Bentley 2010). They could be regulating the effects of pituitary gonadotropins, implicated in rapid local responses or integrated with other neuropeptides in the gonad. Understanding the biological functions of neuropeptide systems in the ovaries will be crucial in determining the potential use of these factors as biomarkers for the quality of developing oocytes and for fertilization ability which might lead to advances in the exploration of new drug targets in the ovary and help to improve the effectiveness of reproductive treatment.

In summary, phoenixin is mainly expressed in the GCs and oocytes of the growing follicles in the ovary, and its expression in GCs increased with the stage of follicle development. In vitro, phoenixin accelerates GC proliferation and acts through GPR173 to stimulate E2 production via CREB signaling to increase the expression of CYP19A1 mRNA. Furthermore, phoenixin increases the expression of FSHR, LHR, KITL and decreases CNP mRNA expression. Phoenixin treatment in murine ovarian tissue culture model increases the follicle area and oocyte maturation. Together, these findings suggest a potential role of phoenixin and GPR173 in promoting follicular growth. Future investigations should address the effect of phoenixin on specific stages of follicle development as well as on other human ovarian cells including theca cells and oocytes and its promising implication in other neuropeptides in the ovary.

\section{Supplementary data}

This is linked to the online version of the paper at https://doi.org/10.1530/REP-19-0025.

\section{Declaration of interest}

The authors declare that there is no conflict of interest that could be perceived as prejudicing the impartiality of the research reported.

\section{Funding}

This work was supported by the Grant-in-Aid for Scientific Research 18K16767 to Tomoko Nakamura from the Japan Society for the Promotion of Science, Japan.

\section{References}

Bauman BM, Yin W, Gore AC \& Wu TJ 2017 Regulation of gonadotropinreleasing hormone-(1-5) signaling genes by estradiol is age dependent. Frontiers in Endocrinology 8 282. (https://doi.org/10.3389/ fendo.2017.00282)

Bayasula, Iwase A, Kiyono T, Takikawa S, Goto M, Nakamura T, Nagatomo Y, Nakahara T, Kotani T, Kobayashi H et al. 2012 Establishment of a human nonluteinized granulosa cell line that transitions from the gonadotropinindependent to the gonadotropin-dependent status. Endocrinology 153 2851-2860. (https://doi.org/10.1210/en.2011-1810)

Bédécarrats GY, Baxter M \& Sparling B 2016 An updated model to describe the neuroendocrine control of reproduction in chickens. General and Comparative Endocrinology 227 58-63. (https://doi.org/10.1016/j. ygcen.2015.09.023) 
Carlezon WA, Duman RS \& Nestler EJ 2005 The many faces of CREB Trends in Neurosciences 28 436-445. (https://doi.org/10.1016/j. tins.2005.06.005)

Carlsson IB, Laitinen MPE, Scott JE, Louhio H, Velentzis L, Tuuri T, Aaltonen J, Ritvos O, Winston RML \& Hovatta O 2006 Kit ligand and C-Kit are expressed during early human ovarian follicular development and their interaction is required for the survival of follicles in longterm culture. Reproduction 131 641-649. (https://doi.org/10.1530/ rep.1.00868)

Conkright MD, Guzmán E, Flechner L, Su Al, Hogenesch JB \& Montminy M 2003 Genome-wide analysis of CREB target genes reveals a core promoter requirement for cAMP responsiveness. Molecular Cell 11 1101-1108. (https://doi.org/10.1016/S1097-2765(03)00134-5)

Drummond AE 2006 The role of steroids in follicular growth. Reproductive Biology and Endocrinology 4 16. (https://doi.org/10.1186/1477-7827-4-16)

Drummond AE \& Findlay JK 1999 The role of estrogen in folliculogenesis. Molecular and Cellular Endocrinology 151 57-64. (https://doi. org/10.1016/S0303-7207(99)00038-6)

Escobar-Morreale HF 2018 Polycystic ovary syndrome: definition, aetiology, diagnosis and treatment. Nature Reviews. Endocrinology 14 270-284. (https://doi.org/10.1038/nrendo.2018.24)

García-Galiano D \& Tena-Sempere M 2013 Emerging roles of NUCB2/ nesfatin-1 in the metabolic control of reproduction. Current Pharmaceutical Design 19 6966-6972. (https://doi.org/10.2174/13816 1281939131127142531)

Garcia-Ortega J, Pinto FM, Fernandez-Sanchez M, Prados N, CejudoRoman A, Almeida TA, Hernandez $M$, Romero $M$, Tena-Sempere $M$ \& Candenas L 2014 Expression of neurokinin B/NK3 receptor and kisspeptin/KISS1 receptor in human granulosa cells. Human Reproduction 29 2736-2746. (https://doi.org/10.1093/humrep/deu247)

Hatzirodos N, Irving-Rodgers HF, Hummitzsch K, Harland ML, Morris SE \& Rodgers RJ 2014 Transcriptome profiling of granulosa cells of bovine ovarian follicles during growth from small to large antral sizes. BMC Genomics 15 24. (https://doi.org/10.1186/1471-2164-15-24)

Hirshfield AN 1991 Development of follicles in the mammalian ovary. International Review of Cytology 124 43-101. (https://doi.org/10.1016/ S0074-7696(08)61524-7)

Hsueh AJW, Kawamura K, Cheng Y \& Fauser BCJM 2015 Intraovarian control of early folliculogenesis. Endocrine Reviews 36 1-24. (https:// doi.org/10.1210/er.2015.36.issue-1.edboard)

Hu KL, Zhao H, Chang HM, Yu Y \& Qiao J 2017 Kisspeptin/kisspeptin receptor system in the ovary. Frontiers in Endocrinology 8 365. (https:// doi.org/10.3389/fendo.2017.00365)

Hutt KJ, McLaughlin EA \& Holland MK 2006a KIT/KIT ligand in mammalian oogenesis and folliculogenesis: roles in rabbit and murine ovarian follicle activation and oocyte growth. Biology of Reproduction 75 421-433. (https://doi.org/10.1095/biolreprod.106.051516)

Hutt KJ, McLaughlin EA \& Holland MK 2006b Kit ligand and c-Kit have diverse roles during mammalian oogenesis and folliculogenesis. Molecular Human Reproduction 12 61-69. (https://doi.org/10.1093/ molehr/gal010)

Jiang JH, He Z, Peng YL, Jin WD, Mu J, Xue HX, Wang Z, Chang M \& Wang R 2015 Effects of Phoenixin-14 on anxiolytic-like behavior in mice. Behavioural Brain Research 286 39-48. (https://doi.org/10.1016/j. bbr.2015.02.011)

Kawamura K, Cheng Y, Kawamura N, Takae S, Okada A, Kawagoe Y, Mulders S, Terada Y \& Hsueh AJW 2011 Pre-ovulatory LH/hCG surge decreases C-type natriuretic peptide secretion by ovarian granulosa cells to promote meiotic resumption of pre-ovulatory oocytes. Human Reproduction 26 3094-3101. (https://doi.org/10.1093/humrep/der282)

Kim J, Chung Y, Kim H, Im E, Lee H \& Yang H 2014 The tissue distribution of Nesfatin-1/NUCB2 in mouse. Development and Reproduction 18 301-309. (https://doi.org/10.12717/devrep.2014.18.4.301)

Kishi H, Kitahara Y, Imai F, Nakao K \& Suwa H 2018 Expression of the gonadotropin receptors during follicular development. Reproductive Medicine and Biology 17 11-19. (https://doi.org/10.1002/rmb2.12075)

Komatsu K, Koya T, Wang J, Yamashita M, Kikkawa F \& Iwase A 2015 Analysis of the effect of leukemia inhibitory factor on follicular growth in cultured murine ovarian tissue. Biology of Reproduction 93 18. (https:// doi.org/10.1095/biolreprod.115.128421)

Kranc W, Budna J, Kahan R, Chachuła A, Bryja A, Ciesiółka S, Borys S, Antosik MP, Bukowska D, Brussow KP et al. 2017 Molecular basis of growth, proliferation, and differentiation of mammalian follicular granulosa cells. Journal of Biological Regulators and Homeostatic Agents 31 1-8.

Matsumoto M, Saito T, Takasaki J, Kamohara M, Sugimoto T, Kobayashi M, Tadokoro M, Matsumoto SI, Ohishi T \& Furuichi K 2000 An evolutionarily conserved G-protein coupled receptor family, SREB, expressed in the central nervous system. Biochemical and Biophysical Research Communications 272 576-582. (https://doi.org/10.1006/ bbrc.2000.2829)

McGuire NL \& Bentley GE 2010 Neuropeptides in the gonads: From evolution to pharmacology. Frontiers in Pharmacology 1 114. (https:// doi.org/10.3389/fphar.2010.00114)

Menon KMJ \& Menon B 2012 Structure, function and regulation of gonadotropin receptors - A perspective. Molecular and Cellular Endocrinology 356 88-97. (https://doi.org/10.1016/j.mce.2012.01.021)

Menon KMJ, Clouser CL \& Nair AK 2005 Gonadotropin receptors: role of post-translational modifications and post-transcriptional regulation. Endocrine 26 249-257. (https://doi.org/10.1385/ENDO:26:3:249)

Murase T, Iwase A, Komatsu K, Bayasula, Nakamura T, Osuka S, Takikawa S, Goto M, Kotani T \& Kikkawa F 2018 Follicle dynamics: visualization and analysis of follicle growth and maturation using murine ovarian tissue culture. Journal of Assisted Reproduction and Genetics 35 339-343. (https://doi.org/10.1007/s10815-017-1073-5)

Nakamura T, Iwase A, Bayasula B, Nagatomo $Y$, Kondo $M$, Nakahara T, Takikawa S, Goto M, Kotani T, Kiyono T et al. 2015 CYP51A1 induced by growth differentiation factor 9 and folliclestimulating hormone in granulosa cells is a possible predictor for unfertilization. Reproductive Sciences 22 377-384. (https://doi. org/10.1177/1933719114529375)

Osuka S, Iwase A, Nakahara T, Kondo M, Saito A, Bayasula NT, Takikawa S, Goto M, Kotani T et al. 2016 Kisspeptin in the hypothalamus of two rat models of polycystic ovary syndrome. Endocrinology 158 367-377. (https://doi.org/10.1210/en.2016-1333)

Owens LA, Abbara A, Lerner A, O'floinn S, Christopoulos G, Khanjani S, Islam R, Hardy K, Hanyaloglu AC, Lavery SA et al. 2018 The direct and indirect effects of kisspeptin-54 on granulosa lutein cell function. Human Reproduction 33 292-302. (https://doi.org/10.1093/humrep/dex357)

Prinz P, Scharner S, Friedrich T, Schalla M, Goebel-Stengel M, Rose M \& Stengel A 2017 Central and peripheral expression sites of phoenixin-14 immunoreactivity in rats. Biochemical and Biophysical Research Communications 493 195-201. (https://doi.org/10.1016/j. bbrc.2017.09.048)

Rocca C, Scavello F, Granieri MC, Pasqua T, Amodio N, Imbrogno S, Gattuso A, Mazza R, Cerra MC \& Angelone T 2018 Phoenixin-14: detection and novel physiological implications in cardiac modulation and cardioprotection. Cellular and Molecular Life Sciences 75 743-756. (https://doi.org/10.1007/s00018-017-2661-3)

Roy SK, Wang C, Mukherjee A \& Chakraborty P 2012 In vitro culture of fetal ovaries: A model to study factors regulating early follicular development. Methods in Molecular Biology 825 151-171. (https://doi. org/10.1007/978-1-61779-436-0_12)

Sánchez F \& Smitz J 2012 Molecular control of oogenesis. Biochimica et Biophysica Acta 1822 1896-1912. (https://doi.org/10.1016/j. bbadis.2012.05.013)

Schalla MA \& Stengel A 2018 Phoenixin-A pleiotropic gut-Brain peptide. International Journal of Molecular Sciences 19 1726. (https://doi. org/10.3390/ijms19061726)

Stein LM, Tullock CW, Mathews SK, Garcia-Galiano D, Elias CF, Samson WK \& Yosten GLC 2016 Hypothalamic action of phoenixin to control reproductive hormone secretion in females: importance of the orphan G protein-coupled receptor Gpr173. American Journal of Physiology. Regulatory, Integrative and Comparative Physiology 311 R489-R496. (https://doi.org/10.1152/ajpregu.00191.2016)

Stein LM, Haddock CJ, Samson WK, Kolar GR \& Yosten GLC 2018 The phoenixins: From discovery of the hormone to identification of the receptor and potential physiologic actions. Peptides 106 45-48. (https:// doi.org/10.1016/j.peptides.2018.06.005)

Stocco C 2008 Aromatase expression in the ovary: hormonal and molecular regulation. Steroids 73 473-487. (https://doi.org/10.1016/j. steroids.2008.01.017)

Thomas FH \& Vanderhyden BC 2006 Oocyte-granulosa cell interactions during mouse follicular development: regulation of kit ligand expression 
and its role in oocyte growth. Reproductive Biology and Endocrinology 4 19. (https://doi.org/10.1186/1477-7827-4-19)

Treen AK, Luo V \& Belsham DD 2016 Phoenixin activates immortalized $\mathrm{GnRH}$ and kisspeptin neurons through the novel receptor GPR173. Molecular Endocrinology $30 \quad 872-888 . \quad$ (https://doi.org/10.1210/ me.2016-1039)

Ullah K, ur Rahman T, Wu DD, Lin XH, Liu Y, Guo XY, Leung PCK, Zhang RJ, Huang HF \& Sheng JZ 2017 Phoenixin-14 concentrations are increased in association with luteinizing hormone and nesfatin-1 concentrations in women with polycystic ovary syndrome. Clinica Chimica Acta $\mathbf{4 7 1}$ 243-247. (https://doi.org/10.1016/j.cca.2017.06.013)

Xiao S, Duncan FE, Bai L, Nguyen CT, Shea LD \& Woodruff TK 2015 Size-specific follicle selection improves mouse oocyte reproductive outcomes. Reproduction 150 183-192. (https://doi.org/10.1530/REP15-0175)

Yosten GLC, Lyu RM, Hsueh AJW, Avsian-Kretchmer O, Chang JK, Tullock CW, Dun SL, Dun N \& Samson WK 2013 A novel reproductive peptide, Phoenixin. Journal of Neuroendocrinology 25 206-215. (https:// doi.org/10.1111/j.1365-2826.2012.02381.x)

Zhang P, Wang J, Lang H, Wang W, Liu X, Liu H, Tan C, Li X, Zhao Y \& Wu X 2018 Knockdown of CREB1 promotes apoptosis and decreases estradiol synthesis in mouse granulosa cells. Biomedicine and Pharmacotherapy 105 1141-1146. (https://doi.org/10.1016/j. biopha.2018.06.101)

Received 18 January 2019

First decision 14 February 2019

Revised manuscript received 20 March 2019

Accepted 1 April 2019 